\title{
Peranan Good Corporate Governance Dalam Meminimalisir Praktik Penghindaran Pajak Pada Perusahaan Go Publik
}

\author{
Andrew Gunawan \\ Universitas Katolik Musi Charitas \\ andrew@ukmc.ac.id
}

*Corresponding Author

Diajukan :21 Desember 2021

Disetujui : :26 Desember 2021

Dipublikasi : 1 Januari 2022

\begin{abstract}
The principle of responsibility is one of the important points in the sustainability of a company. Unfortunately, this principle is often ignored, one of which is the prevalence of tax avoidance practices. Tax avoidance is not something "wrong" and violates the "law", but it is considered a bad practice from the perspective of investors' perceptions. In order to suppress this bad practice, a good governance system or what is often referred to as "Good Corporate Governance" has emerged. The results of the study found that the proportion of the board of commissioners who mastered accounting practices was unable to influence tax avoidance.
\end{abstract}

Keywords: GCG, Tax Avoidance, Corporate Governance, Responsibility

\section{PENDAHULUAN}

Prinsip responsibility menjadi salah satu poin penting dalam keberlanjutan sebuah perusahaan. Sayangnya prinsip ini seringkali diabaikan salah satunya dengan maraknya praktik penghindaran pajak. Contohnya saja kasus penghindaran pajak di Indonesia yang dilakukan oleh raksasa teknologi, Google. Penghindaran pajak yang dilakukan oleh Google dengan cara mendirikan kantor pusatnya di negara yang memiliki tarif pajak rendah. Padahal, keuntungan perusahaan berasal dari negara lain seperti Indonesia. Salah satunya, iklan pada situs yang bisa diakses dari seluruh penjuru dunia (cnnindonesia.com).

Selain kasus penghindaran pajak oleh Google, kasus lainnya yang sempat menghebohkan adalah kasus PT.Adaro Energy Tbk dengan kode emiten ADRO yang merupakan perusahaan tambang terkemuka di Indonesia. Global Witness menyebutkan bahwa perusahaan tambang besar di Indonesia, PT. Adaro Energy Tbk melakukan akal-akalan pajak. Adaro disebut melakukan transfer pricing melalui anak usahanya di Singapura, Coaltrade Services International. Upaya itu disebutkan telah dilakukan sejak 2009 hingga 2017. Adaro diduga telah mengatur sedemikian rupa sehingga mereka bisa membayar pajak US\$ 125 juta atau setara $R p 1,75$ triliun (kurs Rp 14 ribu) lebih rendah daripada yang seharusnya dibayarkan di Indonesia (finance.detik.com).

Contoh tersebut menunjukkan fenomena yang unik, bahwasannya praktik penghindaran pajak masi seringkali dilakukan walaupun oleh perusahaan nasional ataupun multinasional sekalipun. Hal ini ditimbulkan karena celah dalam sistem perpajakan di Indonesia. Sistem perpajakkan di Indonesia sendiri yang menganut sistem Self Assessment System, yaitu sistem perpajakkan yang memberikan kebebasan bagi para Wajib Pajak untuk menghitung, membayar, serta melaporkan sendiri kewajiban perpajakkannya. Maka dari itu peran dari pihak pemerintah maupun Kantor Pelayanan Pajak (KPP) mereka hanya mengawasi tidak ikut terlibat secara langsung dalam proses perhitungannya. Sering kali dengan adanya penerapan sistem perpajakkan ini yang ada dalam Undang - Undang Perpajakkan Indonesia seakan - akan memberikan kesempatan bagi para Wajib Pajak untuk mengurangi jumlah pajak yang harus dibayarkan, salah satunya dengan praktik penghindaran pajak atau tax avoidance. 


\section{Owner: Riset \& Jurnal Akuntansi}

e-ISSN : 2548-9224 | p-ISSN : 2548-7507

Volume 6 Nomor 1, Januari 2022

DOI : https://doi.org/10.33395/owner.v6i1.618

Penghindaran pajak atau (Tax Avoidance) didefinisikan sebagai suatu upaya penghindaran pajak yang dilakukan secara legal dan aman bagi Wajib Pajak tanpa bertentangan dengan ketentuan perpajakan yang berlaku, dimana metode dan teknik yang digunakan cenderung memanfaatkan kelemahan - kelemahan yang terdapat dalam Undang - Undang dan Peraturan Perpajakan itu sendiri (Pohan, 2019). Seringkali terjadi argumentasi mengenai : "penghindaran pajak ini bukanlah sesuatu yang salah, karena tidak menyalahi aturan dan perundang-undangan yang berlaku".

Penghindaran pajak memang bukan sesuatu yang "salah" dan melanggar "undang-undang", namun hal ini dianggap sebagai praktik yang kurang baik dan tidak etis khususnya dari sisi persepsi investor. Kenapa dianggap tidak etis? Karena seyogyanya perusahaan yang baik akan lebih mengedepankan aspek responsibility dan menjaga kredibilitasnya. Investor mempercayai bahwa perusahaan yang mampu memenuhi kewajiban pajak adalah perusahaan yang juga akan mengedepankan kewajibannya kepada investor. Setidaknya ini yang ada di pemikiran mayoritas investor.

Salah satu cara untuk menekan praktik penghindaran pajak adalah dengan penerapan sistem tata kelola yang baik atau yang sering disebut sebagai "Good Corporate Governance" (GCG). Tata kelola perusahaan atau biasa dikenal dengan sebutan Good Corporate Governance (GCG) merupakan sistem yang mengelola dan mengawasi proses pengendalian usaha yang berjalan secara berkesinambungan untuk menaikkan nilai saham, yang akhirnya akan meningkatkan nilai perusahaan sebagai bentuk pertanggungjawaban kepada shareholders tanpa mengabaikan kepentingan stakeholders yang meliputi karyawan, kreditur dan masyarakat (Franita, 2018).

Salah satu Komponen GCG yang memang ditenggarai mampu untuk melakukan pengawasan atas praktik negatif spesifik adalah dewan komisaris yang menguasai praktik akuntansi. Dengan kehadiran mereka, diharapkan praktik-praktik kurang etis seperti penghindaran pajak dapat diminimalisir. Alasannya, ketika dewan komisaris menguasi praktik-praktik akuntansi, maka mereka diharapakan dapat mengidentifikasi dan mengawasi praktik kurang etis utamanya pelaporan keuangan bagi stakeholder yakni pemerintah dalam hal ini perpajakan, investor, dan masyrakat.

Berdasarkan pada fenomena dan argumentasi logis yang telah dijelaskan diatas, maka penelitian ini akan membahas secara detil terkait "Peranan Good Corporate Governance Dalam Meminimalisir Praktik Penghindaran Pajak Pada Perusahaan Go Public"

\section{Teori Agensi}

\section{STUDI LITERATUR}

Teori agensi ini menjelaskan hubungan antara agent dan principal. Menurut Jensen dan Meckling (1976) dalam Subagiastra dkk (2016) menyatakan bahwa teori keagenan sebagai suatu kontrak dimana satu orang atau lebih (principal) melibatkan satu orang (agent). Secara garis besar digambarkan dua bentuk hubungan keagenan, yaitu antara manajer dengan pemegang saham (shareholders) dan antara manajer dengan pemberi pinjaman (bondholders). Menurut Lukviarman dalam (Subagiastra et al., 2016) Agency Theory merupakan perspektif yang jelas mengambarkan masalah yang timbul dengan adanya pemisahan antara kepemilikan dan pengendalian terhadap perusahaan, yaitu adanya konflik kepentingan dalam perusahaan.

Manajer dalam menjalankan tugasnya memiliki tujuan pribadi yang bertentangan dengan tujuan dari prinsipal, dalam hal ini tujuan dari prinsipal ialah untuk memaksimalkan kemakmuran pemegang saham. Dikarenakan informasi yang lebih banyak dimiliki oleh pihak manajer ini dapat memicu mereka untuk melakukan tindakkan yang sesuai dengan keinginan dan kepentingan untuk memaksimalkan kinerja mereka sendiri seperti agar dapat dinilai kinerjanya baik maka mereka cenderung akan melakukan praktik penghindaran pajak. Sedangkan bagi pemilik modal dalam hal ini investor, bagi mereka akan sulit untuk mengontrol secara efektif tindakan yang dilakukan oleh pihak manajemen ini karena kurangnya informasi yang ada. Maka dari itu, terkadang beberapa kebijakan tertentu yang dilakukan oleh pihak manajemen perusahaan dilakukan tanpa sepengetahuan dari pihak pemilik modal atau investor. 
Owner: Riset \& Jurnal Akuntansi

e-ISSN : 2548-9224 | p-ISSN : 2548-7507

Volume 6 Nomor 1, Januari 2022

DOI : https://doi.org/10.33395/owner.v6i1.618

\section{Teori Asimetri Informasi}

Ketidakseimbangan informasi dalam hal ini ialah pengungkapan laporan keuangan, dimana laporan keuangan ini nantinya akan digunakan oleh berbagai pihak termasuk bagi pihak internal perusahaan (manajemen perusahaan) dan pihak eksternal perusahaan (investor). Laporan keuangan ini lebih penting bagi pihak eksternal dibandingkan pihak internal karena pihak eksternal memiliki pengaruh yang lebih daripada pihak internal.

Asimetri informasi atau ketidakseimbangan informasi ini menimbulkan terjadinya konflik antara pihak manajer dengan pihak pemegang saham yang dimana saling mencoba memanfaatkan masing - masing pihak untuk kepentingannya sendiri. Eisenhardt (1998) dalam (Lisa, 2012) mengemukakan ada tiga asumsi sifat dasar manusia yakni:

1. Manusia pada umumnya mementingkan diri sendiri (self interest).

2. Manusia memiliki daya pikir terbatas mengenai persepsi masa yang akan datang (bounded rationality).

3. Manusia selalu menghindari resiko (risk adverse)

\section{Penghindaran Pajak}

Tax Avoidance atau penghindaran pajak merupakan suatu upaya penghindaran pajak yang dilakukan secara legal dan aman bagi Wajib Pajak tanpa bertentangan dengan ketentuan perpajakan yang berlaku, dimana metode dan teknik yang digunakan cenderung memanfaatkan kelemahan kelemahan yang terdapat dalam Undang - Undang dan Peraturan Perpajakan itu sendiri (Pohan, 2019:370).

Sistem perpajakkan di Indonesia sendiri yang menganut sistem Self Assessment System, yaitu sistem perpajakkan yang memberikan kebebasan bagi para Wajib Pajak untuk menghitung, membayar, serta melaporkan sendiri kewajiban perpajakkannya. Maka dari itu peran dari pihak pemerintah maupun Kantor Pelayanan Pajak (KPP) mereka hanya mengawasi tidak ikut terlibat secara langsung dalam proses perhitungannya. Sering kali dengan adanya penerapan sistem perpajakkan ini yang ada dalam Undang - Undang Perpajakkan Indonesia seakan - akan memberikan kesempatan bagi para Wajib Pajak untuk mengurangi jumlah pajak ang harus dibayarkan. Dalam hal ini tentu saja Wajib Pajak tersebut ialah pihak perusahaan. Perusahaan akan cenderung meminimalisir beban pajak yang akan dibayarkan. Di satu sisi tax avoidance ini diperbolehkan, akan tetapi di sisi lain juga tax avoidance tidak diinginkan. Berdasarkan Komite urusan Fiskal dari Organization for Economic Coorperation and Development (OECD) menyebutkan ada tiga karakter penghindaran pajak (Suandy, 2008:7) :

1. Adanya unsur artifisial dimana berbagai pengaturan seolah-olah terdapat di dalamnya padahal tidak, dan ini dilakukan karena ketiadaan faktor pajak.

2. Memanfaatkan loopholes dari Undang - Undang atau menerapkan ketentuan ketentuan legal untuk berbagai tujuan padahal bukan itu yang sebetulnya dimaksudkan oleh pembuat Undang - Undang.

3. Para konsultan menunjukkan alat atau cara untuk melakukan penghindaran pajak dengan syarat wajib pajak menjaga rahasia mungkin (Council Off Ekecutive Secretaries of Tax

\section{Hipotesis} Organization, 1991)

Berdasarkan teori asimetri informasi, praktik-prakti negatif dan kurang etis biasanya terjadi karena perbedaan kandungan informasi antaran principle dan agent. Perbedaan kandungan informasi inilah yang menyebabkan terjadinya praktik-praktik kurang etis tanpa sepengetahuan stakeholder. Masalah ini pada dasarnya dapat diatasi apabila diterapkan mekanisme pengawasan yang baik dalam tata kelola perusahaan yang baik (GCG).

Salah satu mekanisme yang dianggap ampuh adalah Good Corporate Governance (GCG) utamanya proporsi dewan komisaris yang menguasai praktik akuntansi. Diharapkan dengan adanya dewan komisaris yang menguasai praktik akuntansi, maka praktik-praktik kurang etis seperti penghindaran pajak dapat dihindari. Berdasarkan pada argumentasi tersebut, maka pengembangan hipotesis dalam penelitian ini adalah

\section{H1: Proporsi dewan komisaris yang menguasai praktik akuntansi berpengaruh negatif terhadap praktik penghindaran pajak}


Owner: Riset \& Jurnal Akuntansi

e-ISSN : 2548-9224 | p-ISSN : 2548-7507

Volume 6 Nomor 1, Januari 2022

DOI : https://doi.org/10.33395/owner.v6i1.618

\section{Populasi dan Sampel}

METODE

Populasi dalam penelitian ini adalah seluruh perusahaan pertambangan yang terdaftar di Bursa Efek Indonesia semenjak tahun 2015 - 2019. Teknik sampling yang digunakan dalam penelitian ini adalah purposive sampling, dengan kriteria sebagai berikut:

1. Perusahaan pertambangan yang tidak didelisting baik secara paksa maupun sukarela pada periode pengamatan 2015 - 2019. Hal ini dikarenakan apabila perusahaan didelisting apalagi secara paksa, maka "kebenaran" data keuangan yang selama ini dipublikasi patut dipertimbangkan.

2. Perusahaan pertambangan yang memiliki komisaris yang menguasai praktik akuntansi

\section{Teknik Pengumpulan Data}

Teknik pengumpulan data dengan menggunakan teknik dokumentasi. Sumber tersebut dapat berupa informasi atau laporan dari Bursa Efek Indonesia dan situs atau website perusahaan itu sendiri.

\section{Teknik Analisis Data}

Teknik analisis data yang akan digunakan dalam penelitian ini adalah regresi linear sederhana menggunakan program SPSS versi 23. Adapun model regresi yang digunakan dalam penelitian ini adalah:

$\mathrm{CETR}=\beta \mathrm{DKA}+\mathrm{e}$

Keterangan:

CETR : Penghindaran Pajak

$\beta \quad$ : Konstanta

DKA :Dewan Komisaris yang Menguasai Praktik Akuntansi

$\varepsilon \quad:$ Standar error

Sebelum melakukan uji regresi sederhana, maka terlebih dahulu peneliti akan melakukan uji statistik deskriptif. Setelah itu, untuk memastikan bahwa model regresi yang dibuat diatas dapat digunakan untuk menguji hipotesis, maka dilakukan pengujian model regresi. Pengujian model regresi dilakukan agar model regresi yang digunakan untuk menjawab hipotesis terbebas dari permasalahan seperti normalitas data, maka perlu dilakukan screening data. Setelah melakukan screening data, maka langkah selanjutnya melakukan uji asumsi klasik seperti heterokedastisitas, autokorelasi

\section{Data Penelitian}

\section{HASIL}

Berdasarkan pada seleksi sampel berdasarkan kriteria penelitian dengan menggunakan teknik purposive sampling, maka didapatkan jumlah sampel yang memenuhi syarat sebesar 124 data. Adapun rinciannya ditunjukkan pada tabel 4.1 berikut ini:

Tabel 1

Penentuan Sampel Penelitian

\begin{tabular}{clc}
\hline No. & \multicolumn{1}{c}{ Kriteria Penentuan Sampel } & Jumlah \\
\hline 1. & $\begin{array}{l}\text { Jumlah perusahaan pertambangan yang terdaftar di BEI } \\
\text { periode 2015-2019 }\end{array}$ & 12 \\
\hline 2. & Perusahaan yang didelisting / dibekukan & $(1)$ \\
\hline 3. & Perusahaan yang merger dan akuisisi & $(0)$ \\
\hline & Jumlah perusahaan yang diamati & $\mathbf{1 1}$ \\
\hline 4. & Periode pengamatan lima tahun & 5 \\
\hline & Jumlah pengamatan data & $\mathbf{5 5}$ \\
\hline 5. & Data yang tidak lengkap/ tidak tersedia & 0 \\
\hline & Jumlah data akhir yang bisa diolah & $\mathbf{5 5}$ \\
\hline
\end{tabular}

Sumber: Data yang diolah

Berdasarkan tabel tersebut dapat terlihat bahwasannya terdapat 55 perusahaan pertambangan yang terdaftar di BEI sepanjang 2016-2018. Namun dari jumlah tersebut, sebanyak 1 perusahaan harus dibekukan, yakni_PT. Trada Alam Minera (TRAM). Hal_ini_membuat data pengamatan menjadi 41 perusahaan 
Owner: Riset \& Jurnal Akuntansi

e-ISSN : 2548-9224 | p-ISSN : 2548-7507

Volume 6 Nomor 1, Januari 2022

DOI : https://doi.org/10.33395/owner.v6i1.618

pertambangan yang kemudian dikalikan dengan periode pengamatan selama 5 tahun menjadi 55 pengamatan data.

\section{Screening Data (Uji Normalitas)}

Uji Normalitas pada penelitian ini menggunakan uji Kolmogorov Smirnov dengan program SPSS 23. Adapun hasil pengujian normalitas data pada penelitian ini ditunjukkan pada tabel berikut ini

Tabel 2

Hasil Uji Normalitas

\begin{tabular}{|c|c|c|}
\hline & DKA & CETR \\
\hline N & 55 & 55 \\
\hline Asymp. Sig. (2-tailed) & 0,000 & 0,000 \\
\hline
\end{tabular}

Sumber: data yang diolah peneliti

Berdasarkan pada hasil tabel diatas, dapat dilihat bahwa semua variabel dalam penelitian ini tidak memenuhi asumsi normalitas, oleh karena itu peneliti akan mencoba melakukan perbaikan dengan melakukan trimming data outlier. Karena sampel dalam penelitian ini merupakan sampel besar, menurut Ghozali (2015) untuk data dengan sampel besar maka suatu data dinyatakan sebagai outlier apabila besaran data lebih dari -3 dan +3 . Setelah dilakukan outlier maka ditemukan 9 observasi data yang nilai Z-Scorenya melebih -3 ataupun +3 sehingga jumlah observasi yang tersisa sebanyak 52 pengamatan.

Setelah dilakukan trimming outlier, maka langkah selanjutnya adalah menguji normalitas data kembali, namun hasilnya tidak berbeda jauh dan data tetap dinyatakan tidak normal seperti yang terlihat pada tabel berikut ini:

Tabel 3

Hasil Uji Normalitas Setelah Trimming Outlier

\begin{tabular}{|c|c|c|}
\hline & DKA & CETR \\
\hline $\mathrm{N}$ & 52 & 52 \\
\hline Asymp. Sig. (2-tailed) & 0,000 & 0,000 \\
\hline
\end{tabular}

Sumber: data yang diolah peneliti

Langkah selanjutnya peneliti mencoba melakukan transformasi data dengan menggunakan semi transform SQRT karena arah histogram data menunjukkan indikasi terjadinya moderate positive skewness. Selain itu data variabel CETR juga di-normalized untuk menyetarakan jangkauan data yang terlalu jauh antara variabel yang satu dengan yang lain (Liang, Liu, Tsai, 2014). Namun hasil pengujian normalitas tetap menunjukkan bahwa hanya data variabel DKA yang terdistribusi secara normal, sementara data variabel lainnya tidak terdistribusi secara normal, hal ini ditunjukkan pada tabel berikut:

Tabel 4

Hasil Uji Normalitas Setelah Transform dan Normalized

\begin{tabular}{|c|c|c|}
\hline & SQDKA & NCETR \\
\hline $\mathrm{N}$ & 55 & 55 \\
\hline Asymp. Sig. (2-tailed) & 0,000 & 0,000 \\
\hline
\end{tabular}

Sumber: data yang diolah peneliti

Apabila asumsi normalitas sebuah data masi tidak dapat dipenuhi setelah dilakukan semua langkah perbaikan diatas, maka peneliti dapat menggunakan alternatif pengujian non-parametrik atau menggunakan data apa adanya (Santoso, 2014). Dalam penelitian ini, peneliti lebih memilih untuk menggunakan asumsi non parametrik dengan tetap menggunakan Macro Indirect dari Preacher \& Hayes (2008) dengan menambahkan performa resampling yakni Bootstraping sebagai alternatif pengujian tanpa mengabaikan power of test dalam sebuah penelitian. Adapun besaran resampling yang digunakan adalah $1000 \mathrm{x}$.

\section{Pengujian Hipotesis}

Uji Hipotesis pada penelitian ini akan menggunakan software SPPS 23 dengan perform Bootstraping untuk menguji pengaruh proporsi dewan komisaris yang menguasai praktik akuntansi terhadap penghindaran pajak yang diproksikan dengan CETR. Uji pertama yang akan dilakukan adalah koefisien determinasi yang ditunjukkan pada tabel berikut:

Tabel 5

Hasil Uji Koefisien Determinasi

\begin{tabular}{cc}
\hline Model & Adjusted R Square \\
\hline $\mathbf{1}$ & 0,005 \\
\hline Sumber : data diolah
\end{tabular}

Hasil dari tabel diatas menunjukkan bahwasannya seluruh variabel independen dalam penelitian ini hanya mampu menjelaskan hubungannya dengan variabel dependen sebesar 0,5\%, sementara 99,5\% 
Owner: Riset \& Jurnal Akuntansi

e-ISSN : 2548-9224 | p-ISSN : 2548-7507

Volume 6 Nomor 1, Januari 2022

DOI : https://doi.org/10.33395/owner.v6i1.618

dipengaruhi oleh variabel lain diluar penelitian ini. Sementara itu hasil pengujian anova atau uji $F$, ditunjukkan pada tabel berikut ini:

Tabel 5.6

Hasil Uji F

\begin{tabular}{ccc}
\hline Model & F & Sig \\
\hline Regression & 1,298 & 0,260 \\
\hline \multicolumn{2}{l}{ Sumber : data diolah peneliti }
\end{tabular}

Sumber : data diolah peneliti

Berdasarkan hasil pengujian tersebut, dapat dilihat bahwasannya nilai signifikansinya berada di angka $0,260>0,05$. Hal ini menunjukkan bahwa model dalam penelitian ini kurang baik untuk digunakan atau $F$ ditolak. Setelah melakukan pengujian F, maka langkah selanjutnya adalah menguji hipotesis. Hasil pengujian hipotesis dengan menggunakan metode bootstraping ditunjukkan sebagai berikut:

\begin{tabular}{cc}
\multicolumn{2}{c}{ Tabel 5.7 } \\
Hasil Uji t \\
\hline Model & Sig \\
\hline DKA & 0,152 \\
\hline Sumber $:$ data diolah peneliti
\end{tabular}

Sumber : data diolah peneliti

Berdasarkan hasil uji t diatas, dapat diketahui bahwa hipotesis yang menyatakan terdapat pengaruh positif antara proporsi dewan komisaris yang menguasai praktik akuntansi terhadap penghindaran pajak pertambangan di Indonesia ditolak.

\section{PEMBAHASAN}

Jika ditinjau melalui teori agensi, peran dewan komisaris khususnya mereka yang menguasai praktik akuntansi atau berlatar belakang pendidikan bisnis harusnya mampu untuk mengatasi praktik-praktik negatif yang mungkin terjadi dalam manajemen perusahaan sebagai akibat dari adanya perbedaan kepentingan dan asimetri informasi. Namun Berdasarkan pada hasil statistik yang telah diuji, diketahui bahwa proporsi dewan komisaris yang menguasai praktik akuntansi tidak berpengaruh terhadap penghindaran pajak pertambangan di Indonesia.

Ada 2 hal yang menyebabkan proporsi dewan komisaris yang menguasai praktik akuntansi belum mampu mempengaruhi praktik penghindaran pajak. Pertama, masi banyak komisaris yang menjabat hanya sekadar sebagai sarana untuk memenuhi ketentuan regulator. Kedua, jumlah dewan komisaris yang menguasai praktik akuntansi masi sangat minim, tercatat rata-rata hanya $1 / 3$ atau bahkan $1 / 5$ dari komisaris yang ada yang memiliki latar belakang pendidikan akuntansi.

Hal ini tentunya akan membuat mekanisme pengawasan yang dilaksanakan oleh komisaris tersebut menjadi tidak optimal. Apalagi jika hanya 1 orang yang memahami praktik akuntansi dan diharuskan mengawasi dan mengendalikan praktik-praktik negatif yang ada di sebuah perusahaan. Rata-rata perusahaan pertambangan di Indonesia memang masi minim komisari yang berlatar belakang pendidikan akuntansi

\section{KESIMPULAN}

Penelitian ini menemukan bahwa proporsi dewan komisaris yang menguasai praktik akuntansi tidak mampu mempengaruhi penghindaran pajak. Hal ini cukup wajar karena terbatasnya jumlah komisaris yang berlatar belakang akuntansi sehingga mekanisme pengawasan atas praktik-praktik penghindaran pajak menjadi kurang maksimal

\section{REFERENSI}

Arinda, H., \& Dwimulyani, S. (2018). Analisis Pengaruh penghindaran pajak Dan Kualitas Audit Terhadap Tax Avoidance Dengan Good Corporate Governance Sebagai Variabel

Moderasi. Jurnal Akuntansi Trisakti, 5(1), 123-140.

Ariyanti, F. (2016). Membongkar Strategi Penghindaran Pajak Google di Dunia. Retrieved March 13, 2020, from www.liputan6.com

Darmawan, I. G. H., \& Sukartha, I. M. (2014). Pengaruh Penerapan Corporate Governance, Leverage, Return On Assets, Dan Ukuran Perusahaan Pada Penghindaran Pajak. Jurnal Akuntansi Universitas Udayana, 9(1), 143-161.

Diantari, P. R., \& Ulupui, I. A. (2016). Pengaruh Komite Audit, Proporsi Dewan Komisaris Independen, Dan Proporsi Kepemilikan Institusional Terhadap Tax Avoidance. E-Jurnal Akuntansi Universitas Udayana, 16(1), 702-732.

Eksandy, A. (2017). Pengaruh Komisaris Independen, Komite Audit, Dan Kualitas Audit 


\section{Owner: Riset \& Jurnal Akuntansi}

e-ISSN : 2548-9224 | p-ISSN : 2548-7507

Volume 6 Nomor 1, Januari 2022

DOI : https://doi.org/10.33395/owner.v6i1.618

Terhadap Penghindaran Pajak (Tax Avoidance) (Studi Empiris pada Sektor Industri Barang

Konsumsi yang terdaftar di Bursa Efek Indonesia Periode 2010-2014). Competitive, 1(1).

Fadila, M. (2017). Pengaruh Return On Asset, Leverage, Ukuran Perusahaan Kompensasi Rugi

Fiskal, Kepemilikan Institusional, Dan Koneksi Politik Terhadap Penghindaran Pajak

(Studi Empiris Pada Perusahaan Manufakturang Terdaftar Di Bei Tahun 2011- 2015).

JOM Fekon, 4(1).

Franita, R. (2018). Mekanisme Good Corporate Governance Dan Nilai Perusahaan : Studi Untuk Perusahaan Telekomunikasi. (H. Wahyuni, Ed.). Medan: LEMBAGA PENELITIAN

DAN PENULISAN ILMIAH AQLI. Retrieved from https://books.google.co.id

Ghozali, I. (2016). Analisis Multivariate Program IBM SPSS 21 (7th ed.). Semarang: Badan Penerbit Universitas Diponegoro.

Jogiyanto. (2013). Metodologi Penelitian Bisnis : Salah Kaprah dan Pengalaman - Pengalaman (6th ed.). Yogyakarta: BPFE.

Lisa, O. (2012). Asimetri Informasi Dan Manajemen Laba: Suatu Tinjauan Dalam Hubungan Keagenan. Wiga, 2(1).

Otoritas Jasa Keuangan Republik Indonesia. (2014). POJK 33. Direksi dan Dewan Komisaris Emiten Atau Perusahaan Publik.

Pohan, C. A. (2019). Pedoman Lengkap Pajak Internasional Konsep, Strategi, dan Penerapan (Revisi). Jakarta: PT Gramedia Pustaka Utama.

Prima, B. (2019). Dilaporkan Melakukan Penghindaran Pajak, Bentoel Angkat Bicara. Retrieved March 13, 2020, from www.kontan.co.id

Putri, V. R., \& Putra, B. I. (2017). Pengaruh Leverage, Profitability, Ukuran Perusahaan Dan Proporsi Kepemilikan Institusional Terhadap Tax Avoidance. Jurnal Ekonomi Manajemen Sumber Daya, 19(1).

Santoso, S. (2010). Statistik Parametrik: Konsep dan Aplikasi Dengan SPSS. Jakarta: PT Elex Media Komoutindo.

Suandy, E. (2008). Perencanaan Pajak. (M. Teresa, Ed.) (4th ed.). Jakarta: Salemba Empat.

Subagiastra, K., Arizona, I. P. E., \& Mahaputra, I. N. K. A. (2016). Pengaruh Profitabilitas, Kepemilikan Keluarga, Dan Good Corporate Governance Terhadap Penghindaran Pajak (Studi pada Perusahaan Manufaktur di Bursa Efek Indonesia). Jurnal Ilmiah Akuntansi, $1(2), 167-193$.

Sugiyono. (2017). Metode Penelitian Kuantitatif Kualitatif dan R \& D (1st ed.). Bandung: Alfabeta.

Suryowati, E. (2016). Terkuak, Modus Penghindaran Pajak Perusahaan Jasa Kesehatan Asal Singapura. Retrieved March 13, 2020, from www.kompas.com 